\title{
Ocean time-series reveals recurring seasonal patterns of virioplankton dynamics in the northwestern Sargasso Sea
}

\author{
Rachel J Parsons ${ }^{1}$, Mya Breitbart ${ }^{2}$, Michael W Lomas ${ }^{1}$ and Craig A Carlson ${ }^{3}$ \\ ${ }^{1}$ Bermuda Institute of Ocean Science, St George's GE01, Bermuda; ${ }^{2}$ College of Marine Science, University of \\ South Florida, St Petersburg, FL, USA and ${ }^{3}$ Department of Ecology, Evolution and Marine Biology, University \\ of California, Santa Barbara, CA, USA
}

\begin{abstract}
There are an estimated $10^{30}$ virioplankton in the world oceans, the majority of which are phages (viruses that infect bacteria). Marine phages encompass enormous genetic diversity, affect biogeochemical cycling of elements, and partially control aspects of prokaryotic production and diversity. Despite their importance, there is a paucity of data describing virioplankton distributions over time and depth in oceanic systems. A decade of high-resolution time-series data collected from the upper $300 \mathrm{~m}$ in the northwestern Sargasso Sea revealed recurring temporal and vertical patterns of virioplankton abundance in unprecedented detail. An annual virioplankton maximum developed between 60 and $100 \mathrm{~m}$ during periods of summer stratification and eroded during winter convective mixing. The timing and vertical positioning of this seasonal pattern was related to variability in water column stability and the dynamics of specific picophytoplankton and heterotrophic bacterioplankton lineages. Between 60 and $100 \mathrm{~m}$, virioplankton abundance was negatively correlated to the dominant heterotrophic bacterioplankton lineage SAR11, as well as the less abundant picophytoplankton, Synechococcus. In contrast, virioplankton abundance was positively correlated to the dominant picophytoplankton lineage Prochlorococcus, and the less abundant alpha-proteobacteria, Rhodobacteraceae. Seasonally, virioplankton abundances were highly synchronous with Prochl orococcus distributions and the virioplankton to Prochlorococcus ratio remained remarkably constant during periods of water column stratification. The data suggest that a significant fraction of viruses in the mid-euphotic zone of the subtropical gyres may be cyanophages and patterns in their abundance are largely determined by Prochlorococcus dynamics in response to water column stability. This high-resolution, decadal survey of virioplankton abundance provides insight into the possible controls of virioplankton dynamics in the open ocean.
\end{abstract}

The ISME Journal (2012) 6, 273-284; doi:10.1038/ismej.2011.101; published online 11 August 2011

Subject Category: microbial population and community ecology

Keywords: phage; BATS; FISH; Prochlorococcus; SAR11; Sargasso

\section{Introduction}

An estimated $10^{30}$ virioplankton are present in the world's oceans, most of which are phages that infect marine heterotrophic and autotrophic bacterioplankton (Wommack and Colwell, 2000). Since the first documentation of their abundance two decades ago (Bergh et al., 1989), extensive research has demonstrated the significant influence of marine virioplankton on prokaryotic abundance, community structure, genetic exchange and global biochemical cycles (Proctor and Fuhrman, 1990; Fuhrman, 1999; Wommack and Colwell, 2000; Suttle, 2007; Rohwer and Thurber, 2009).

Correspondence: CA Carlson, Department of Ecology, Evolution and Marine Biology, University of California, Santa Barbara, CA 93106, USA.

E-mail: carlson@lifesci.ucsb.edu

Received 18 March 2011; revised 23 June 2011; accepted 23 June 2011; published online 11 August 2011
Virioplankton are a dynamic component of marine environments, with a turnover time of 2-4 days (Suttle and Chen, 1992; Suttle, 1994). Recently, it has also been demonstrated that viruses encompass enormous genetic diversity and can serve as a reservoir of genes for prokaryotic communities (Angly et al., 2006; Dinsdale et al., 2008).

An essential step in examining the ecological impact of marine virioplankton is to measure the temporal and spatial variability of virioplankton abundance in the context of other biological, physical and biogeochemical parameters. Direct counts of virioplankton reveal average surface layer concentrations of $10^{7}$ viruses $\mathrm{ml}^{-1}$ (Bergh et al., 1989; Proctor and Fuhrman, 1990) and an average virus-to-bacterium ratio (VBR) of approximately 10 (Wommack and Colwell, 2000). Virioplankton abundance is typically highest in the euphotic zone and decreases exponentially with depth (Boehme et al., 1993; Hara et al., 1996; Guixa-Boixareu et al., 1999). 
Subsurface maxima in marine virioplankton abundance have been observed between 15 and $150 \mathrm{~m}$ in some systems (Boehme et al., 1993; Hara et al., 1996; Wommack and Colwell, 2000). Spatial studies have demonstrated that surface concentrations of virioplankton are typically greater in coastal environments and decrease toward more open ocean environments (Cochlan et al., 1993; Marchant et al., 2000; Culley and Welschmeyer, 2002), presumably reflecting the decrease in host abundance and overall productivity offshore. Temporal variability has also been examined in a few coastal systems, demonstrating seasonal virioplankton abundance maxima occurring in the late autumn (Bergh et al., 1989; Waterbury and Valois, 1993; Jiang and Paul, 1994; Weinbauer et al., 1995). However, the temporal dynamics of virioplankton in the oligotrophic open ocean is not well characterized. Systematic resolution of the temporal and vertical variability of virioplankton abundance in the oligotrophic open ocean within the context of biological and physical parameters is a critical step toward determining the factors influencing marine virioplankton distributions.

The Bermuda Atlantic Time-Series Study (BATS) site, located in the northwestern Sargasso Sea, is representative of an oligotrophic subtropical gyre system. The BATS site is characterized as a seasonally oligotrophic system that experiences regular patterns of winter convective mixing, with mixed layer depths (MLDs) extending to $150-300 \mathrm{~m}$ (Steinberg et al., 2001). Winter deep mixing followed by water column stratification (MLD $<20 \mathrm{~m}$ ) in late spring affects the vertical and temporal distributions of specific lineages of picophytoplankton and heterotrophic bacterioplankton (Durand et al., 2001; Carlson et al., 2009; Treusch et al., 2009). The depth-resolved biological, physical and chemical data collected at monthly intervals over the past two decades at BATS provide an excellent backdrop to examine patterns and potential controls of oceanic virioplankton abundance. Here, we present the first depth-resolved $(0-300 \mathrm{~m})$, multi-year time-series of virioplankton abundance in an open ocean system. This decade of virioplankton abundance measurements are described in the context of water column stability, bacterioplankton abundance and bacterioplankton community composition.

\section{Materials and methods}

Study site and sample collection

Samples were collected aboard the $R V$ Weatherbird $I I$ or the $R V$ Atlantic Explorer at the BATS site $\left(31^{\circ}\right.$ $40^{\prime} \mathrm{N}, 64^{\circ} 10^{\prime} \mathrm{W}$ ). All cruises were conducted as part of the larger BATS program and sampled at least monthly with biweekly sampling between February and April. This sampling strategy has been successful in revealing the major temporal microbial and biogeochemical patterns at this site (Carlson and Ducklow, 1996; Steinberg et al., 2001; Morris et al., 2005; Carlson et al., 2009; Treusch et al., 2009; Lomas et al., 2010). A broader assessment of the BATS biogeochemical data is presented in Deep Sea Research II in 1996 (volume 43, issues 2-3) and 2001 (volume 48, issues 8-9).

Samples for virioplankton $(0,20,40,60,80,100$, $140,160,200,250$ and $300 \mathrm{~m}$ ) and bacterioplankton $(0,10,20,40,60,80,100,120,140,160,200,250$ and $300 \mathrm{~m}$ ) were collected at the BATS site from January 2000 to December 2009 via conductivity, temperature, depth profiling rosette equipped with $12 \mathrm{l}$ Niskin bottles. The $120 \mathrm{~m}$ virioplankton sample was added after October 2007. Throughout the entire time-series, all virioplankton samples were fixed with $0.02 \mu \mathrm{m}$ filtered formalin $(1 \%$ final concentration), placed in $5 \mathrm{ml}$ cryovials and flash frozen in liquid nitrogen (Wen et al., 2004) until processing (within 12 weeks of collection). Samples for bacterioplankton abundance were fixed with $0.2 \mu \mathrm{m}$ filtered gluteraldehyde (1\% final concentration) and stored at either $4{ }^{\circ} \mathrm{C}$ for $72 \mathrm{~h}$ or flash frozen and subsequently stored at $-80^{\circ} \mathrm{C}$ for up to 6 months until processing as described in Steinberg et al (2001). Storage tests demonstrated no appreciable loss of virioplankton or bacterioplankton abundance when stored in liquid nitrogen for periods up to 6 months (unpublished data). Picophytoplankton samples were collected at the same depths through $250 \mathrm{~m}$ from October 2001 to December 2009 (Casey et al., 2007). Samples for fluorescence in situ hybridization (FISH) of specific heterotrophic bacterioplankton lineages were collected from the upper $300 \mathrm{~m}$ from January 2003 to December 2005 (Carlson et al., 2009).

Biogeochemical and physical data collected at the BATS site are available at http://bats.bios.edu. The MLD was determined as the depth where potential density (sigma- $t$ ) of the water was equal to sea surface sigma- $t$ plus the equivalent in sigma- $t$ to a $0.2{ }^{\circ} \mathrm{C}$ decrease in temperature (Sprintall and Tomczak, 1992). Contour plots were created in Ocean Data View (R Schlitzer, http://odv.awi.de/) with VG Gridding and linear mapping adjusted to the median of each data set. Statistics (Pearson's correlation and two-tailed Student's $t$-test for unequal variances), ratios and percent contributions were determined using Microsoft Excel.

\section{Virioplankton abundance}

Virioplankton abundance was enumerated according to the methods of Noble and Fuhrman (1998). Briefly, water samples were filtered on to $0.02 \mu \mathrm{m}$ Anodisc aluminum oxide filters (Whatman, Kent, UK), stained with SYBR Green I (Molecular Probes Inc., Eugene, OR, USA), and enumerated via epifluorescence microscopy using an Olympus AX70 microscope (Olympus, Tokyo, Japan) equipped with a Toshiba CCD video camera 
(Irvine, CA, USA) and Pro-series Capture Kit version 4.5 (I-CUBE, Crofton, MD, USA). Ten images from each sample were processed with scripts written in Image Pro Plus (Media Cybernetics, Bethesda, MD, USA) for particles sized $0.01-0.27 \mu \mathrm{m}^{2}$, using the clean borders function (cells touching the edge of the image or grid were omitted). We consider these estimates of viral abundance conservative because it is possible that some viral particles less than one pixel were omitted from the final count. We performed pairwise comparisons of automated versus manual enumeration of virioplankton abundance to determine any discrepancies between the two approaches. Samples collected along a gradient from offshore (BATS; $n=92$ ) to onshore waters of Bermuda $(n=32)$ were highly correlated with automated counts being slightly greater than manual counts (slope $=1.07, r=0.99, n=134$ ). The lower estimates of viral abundance from manual counts may have resulted from image fading during enumeration and/or operator fatigue. We argue that for this study, the automated image analysis was the most reliable approach for viral particle enumeration. The coefficient of variation for the automated counts averaged $11 \%(n=1517)$.

\section{Bacterioplankton abundance}

The bacterioplankton samples were filtered onto Irgalan Black stained $0.2 \mu \mathrm{m}$ filters under gentle vacuum $(\sim 100 \mathrm{~mm} \mathrm{Hg})$ and stained with 4,, 6-diamidino-2-phenylindole dihydrochloride $\left(5 \mu \mathrm{g} \mathrm{ml}^{-1}\right.$, DAPI, SIGMA-Aldrich, St Louis, MO, USA; Porter and Feig, 1980). The filtration was done in minimal lighting to ensure DAPI stain preservation. Filters were mounted onto slides with Resolve immersion oil (high viscosity) and stored at $-20^{\circ} \mathrm{C}$. Slides were then enumerated using an AX70 epifluorescent microscope (Olympus) under ultraviolet excitation at $\times 100$ magnification. At least 800 cells per slide (10 fields) were counted. It is noted that this count includes Archaea and all pigmented and nonpigmented bacterioplankton.

Picophytoplankton abundance using flow cytometry Prochlorococcus and Synechococcus were enumerated by FCM using a Becton Dickenson (Franklin Lakes, NJ, USA; formerly Cytopeia) high speed jet-in-air InFlux flow cytometer at an average flow rate of $40 \mu \mathrm{min}^{-1}$. The Influx cytometer used a $488 \mathrm{~nm}$ blue excitation laser, appropriate Chl- $a$ $(692 \pm 20 \mathrm{~nm})$ and phycoerythrin $(580 \pm 15 \mathrm{~nm})$ bandpass filters, calibrated daily with $0.53 \mu \mathrm{m}$ and $2.88 \mu \mathrm{m}$ fluorescent microbeads (Spherotech Inc. Libertyville, IL, USA). Each sample was run for 4-6 min $(\sim 0.2-$ $0.3 \mathrm{ml}$ total volume analyzed), with log-amplified Chl$a$ and phycoerythrin fluorescence, and forward and right angle scatter signals recorded (Durand and Olson, 1996). Spigot (Cytopeia Inc., Seattle, WA, USA) was used for data acquisition and FCS Express
V3 (DeNovo Software, Los Angeles, CA, USA) was used for post-acquisition analysis. Coefficient of variation of triplicate samples was $<5 \%$ for cell concentrations $>200$ cells $\mathrm{ml}^{-1}$.

\section{Fluorescence in situ hybridization}

FISH was used to quantify the abundance of members of the SAR11 and Rhodobacteraceae clades. The probe and hybridization protocol for members of the SAR11 clade are described in Morris et al. (2002). The probe for Rhodobacteraceae (5'-CAACGCTAACC CCCTCCG-3') was used at a final concentration of $2 \mathrm{ng} \mathrm{l}^{-1}$ in hybridization buffer $\left(0.9 \mathrm{~mol}^{-1} \mathrm{NaCl}, 35 \%\right.$ formamide, $20 \mathrm{mmol}^{-1}$ Tris-HCl (pH 7.4) and $0.01 \%$ (w/v) sodium dodecyl sulfate). The hybridization wash temperature was $52^{\circ} \mathrm{C}$. Washes were conducted

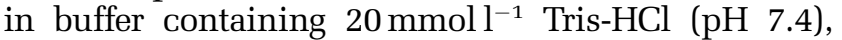
$70 \mathrm{mmol}^{-1} \mathrm{NaCl}, 5 \mathrm{mmoll}^{-1}$ EDTA and $0.01 \%$ sodium dodecyl sulfate. Filters were mounted with $20 \mu \mathrm{l}$ of $1.67 \mu \mathrm{g} \mathrm{ml}^{-1}$ DAPI (SIGMA-Aldrich) in citiflour solution (Ted Pella Inc., Redding, CA, USA) and sealed with nail polish. Image analysis was performed using Cy3 and DAPI filter sets as described by Carlson et al (2009).

\section{Results and Discussion}

Virioplankton dynamics in the context of physical mixing

Virioplankton abundance was determined for 11-12 depths within the surface $300 \mathrm{~m}$ at the BATS site from 2000 through 2009. A total of 137 depth profiles comprising 1517 discrete samples were analyzed during the decadal time-series. Virioplankton distributions demonstrated recurring annual patterns that coincided with annual patterns in water column stability (Figure 1). The MLD of the water column (white line in Figure 1) provides information about the stability of the surface layer of the ocean and was used as a reference to examine variability in virioplankton abundance in time and depth. The MLD extended to depths between 150 and $300 \mathrm{~m}$ in the late winter early spring followed by summer stratification where the MLD shoals to $\sim 10-20 \mathrm{~m}$.

During periods of stratification (that is, MLD $<50 \mathrm{~m}$ ), virioplankton abundance accumulated below the mixed layer, reaching annual maxima of $6-12 \times 10^{9} \mathrm{l}^{-1}$ between 60 and $100 \mathrm{~m}$ in late summer (Figure 1). Euphotic zone virioplankton abundances were observed at minimal values $\left(1-3 \times 10^{9} \mathrm{l}^{-1}\right)$ within the surface mixed layer during periods of summer stratification (Figure 1). Destruction of viral particles or potential loss of hosts as a result of exposure to high levels of ultraviolet radiation (Wommack et al., 1996; Weinbauer and Suttle, 1999; de Araujo and Godinhoa, 2009) may contribute to the observed seasonal virioplankton minimum in the surface mixed layer during stratified periods. 


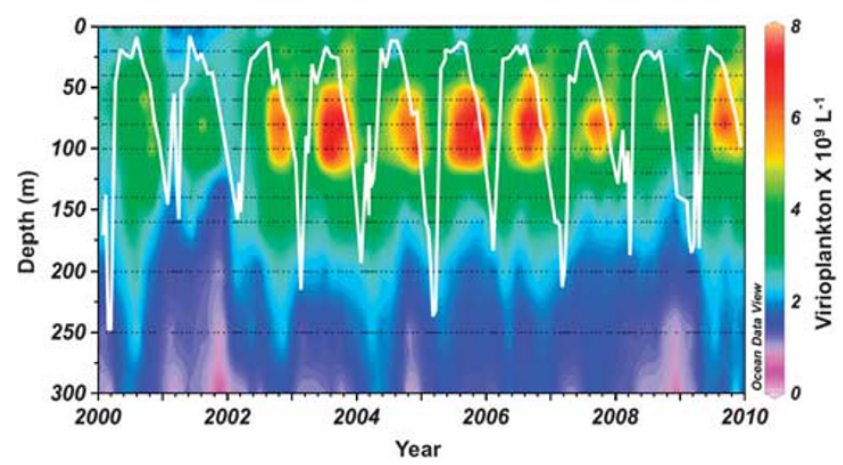

Figure 1 Contour plot of virioplankton abundance $\left(\times 10^{9} \mathrm{l}^{-1}\right)$ over $300 \mathrm{~m}$ from 2000 to 2010 with MLD (m) superimposed as a white line. Each dot represents an individual sampling point.

The onset of convective mixing in early winter (November) eroded the subsurface virus maximum (Figure 1), redistributing and enhancing virioplankton in the near surface when MLD $<100 \mathrm{~m}$. As the MLD deepens to $>150 \mathrm{~m}$, virioplankton abundance first increases (from 1 to $3 \times 10^{9} \mathrm{l}^{-1}$ to $3-4 \times 10^{9} \mathrm{l}^{-1}$ ) in the upper mesopelagic $(140-300 \mathrm{~m})$ followed by an overall reduction of virioplankton abundance (back to $1-2 \times 10^{9} \mathrm{l}^{-1}$ ) within the surface $300 \mathrm{~m}$. Note that elevated mesopelagic virioplankton abundances are observed at depths greater than the maximal MLD for some years (that is, 2000, 2002, 2004 and 2009; Figure 1). These observations imply that mechanisms in addition to convective mixing can be responsible for enhanced virioplankton abundance at depth. Whether virioplankton are delivered to depth via sinking particles or produced by blooms of mesopelagic bacterioplankton (Morris et al., 2005; Carlson et al., 2009; Treusch et al., 2009) remains unknown.

The timing of the development of the subsurface virioplankton maximum $(60-100 \mathrm{~m})$ demonstrated significant interannual variability and was related to the timing of deep convective overturn and subsequent stratification at BATS. Virioplankton abundance consistently reached a yearly maximum below the MLD approximately 7 months after deep mixing (Figure 1).

Although the temporal dynamics of virioplankton abundance coincided with the physical stability of the system, it is the re-distribution of nutrients and the subsequent biological response that ultimately governs virioplankton dynamics. To assess the relationship between the variability of virioplankton and various biogeochemical parameters, Pearson's correlation analyses were performed with integrated and depth-normalized data collected between 60 and $100 \mathrm{~m}$ throughout the time-series record (Table 1). In contrast to Rowe et al (2008), who observed high correlation between virioplankton abundance and chlorophyll $a$ concentrations along large spatial gradients in the Sargasso Sea and North Atlantic, we observed a weak negative correlation between virioplankton abundance and bulk Chl- $a$
Table 1 Pearson's correlation analyses of mean virioplankton abundance versus the biogeochemical variables of nitrate $(\mu \mathrm{mol}$ $\left.\mathrm{kg}^{-1} ; 2000-2008\right)$, phosphate ( $\left.\mu \mathrm{mol} \mathrm{kg}{ }^{-1} ; 2000-2008\right)$, Chl- $a$ ( $\mu \mathrm{g} \mathrm{kg}^{-1}$; 2000-2007), DOC ( $\left.\mathrm{mol} \mathrm{kg}^{-1} ; 2000-2008\right), \mathrm{PP}\left(\mathrm{mg} \mathrm{m}^{-3}\right.$ per day; 2000-2008) and BP (mg m ${ }^{-3}$ per day; 2000-2008)

\begin{tabular}{lll}
$\begin{array}{l}\text { All data } \\
\text { January-December }\end{array}$ & \multicolumn{1}{c}{$\begin{array}{c}\text { MLD-November } \\
\text { May-Nom }\end{array}$} & $\begin{array}{c}\text { MLD }>50 \mathrm{~m} \\
\text { December-April }\end{array}$ \\
\hline $\begin{array}{l}\text { Nitrate } \\
\quad r=-0.24\end{array}$ & $\begin{array}{l}r=-0.26 \\
n=118\end{array}$ & $\begin{array}{l}r=-0.15 \\
n=60\end{array}$ \\
Phosphate & & \\
$\quad r=-0.08$ & $r=-0.05$ & $r=-0.09$ \\
$n=118$ & $n=58$ & $n=60$ \\
Chl-a & & \\
$r=-0.20$ & $r=0.08$ & $r=-0.28$ \\
$n=95$ & $n=47$ & $n=48$ \\
DOC & & \\
$r=0.12$ & $r=0.13$ & $r=0.11$ \\
$n=112$ & $n=57$ & $n=55$ \\
$P P$ & & \\
$r=0.19$ & $r=0.15$ & $r=0.03$ \\
$n=107$ & $n=54$ & $n=53$ \\
BP & & \\
$r=0.13$ & & $r=-0.19$ \\
$n=96$ & $n=0.10$ & $n=46$
\end{tabular}

Abbreviations: BP, bacterial production; DOC, dissolved organic carbon; MLD, mixed layer depth; PP, primary production.

Mean values were first determined by integrating variable between 60 and $100 \mathrm{~m}$ and normalizing to integration depth. All correlations were significant at $P$-values of $<0.0001 ; n$ equals the number of pairwise comparisons. Correlation values are reported for all mean data between 60 and $100 \mathrm{~m}$, and for subsets where the MLD $<50 \mathrm{~m}$ and MLD $>50 \mathrm{~m}$.

through the time-series record $(r=-0.20)$. Virioplankton abundance was also weakly correlated to the other measured environmental parameters (Table 1). Correlation between virioplankton and bulk biogeochemical parameters may be obscured by the trends driven by specific bacterioplankton hosts (see analyses below). In addition to annual patterns of virioplankton dynamics, interannual variability in the subsurface virioplankton maximum was also observed. This interannual variability was consistent with that of some hosts (that is, Prochlorococcus; see discussion below).

\section{Virioplankton dynamics in the context of total bacterioplankton abundance}

Picophytoplankton and heterotrophic bacterioplankton dominate the biological community structure at BATS (Olson et al., 1990; Carlson et al., 1996; Durand et al., 2001; Steinberg et al., 2001; Treusch et al., 2009). Abundance maxima in both virioplankton and total bacterioplankton developed below the MLD during periods of water column stratification (Figure 2a). However, the virioplankton and total bacterioplankton maxima did not coincide temporally or with depth (Figures 2a and 3b). A common 

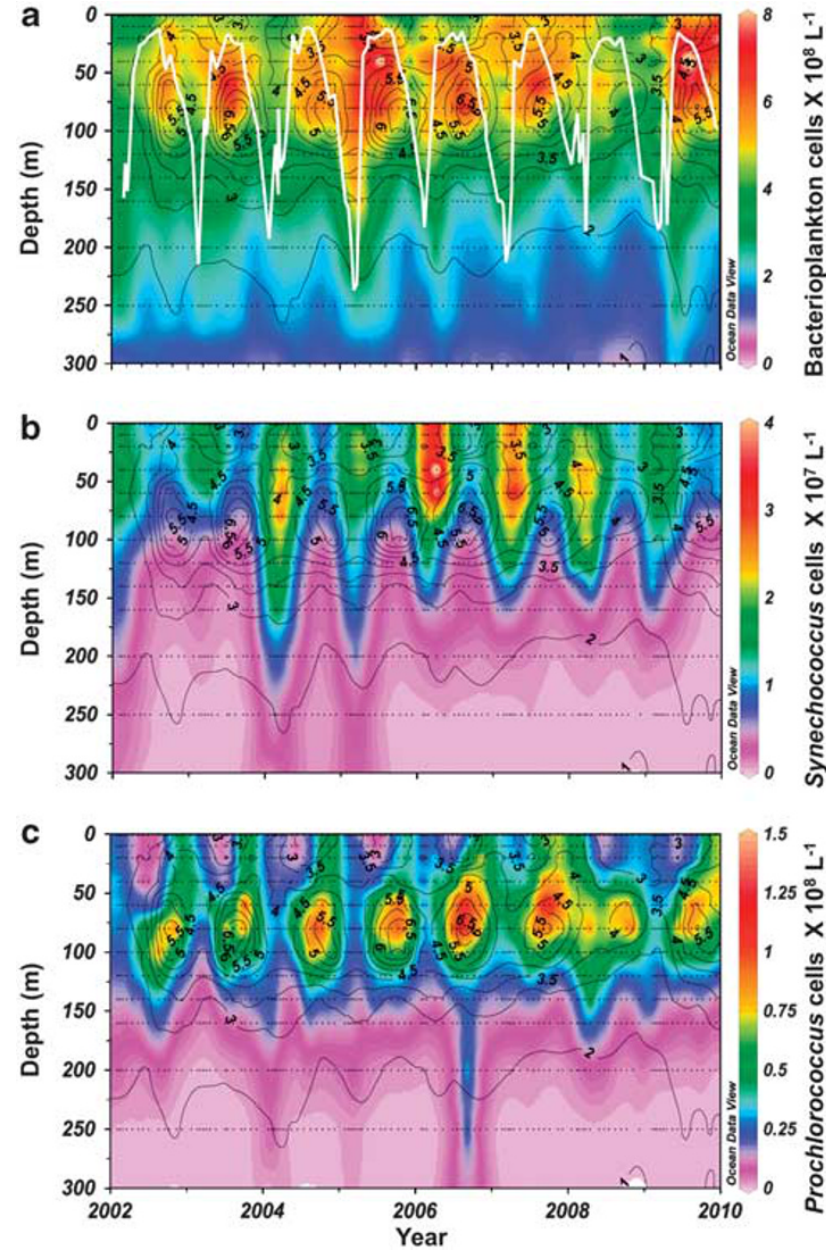

Figure 2 Contour plot of (a) Bacterioplankton $\left(\times 10^{8} \mathrm{l}^{-1}\right)$; (b) Synechococcus $\left(\times 10^{7} \mathrm{l}^{-1}\right)$ and $(\mathbf{c})$ Prochlorococcus $\left(\times 10^{8} \mathrm{l}^{-1}\right)$ cell abundance over $300 \mathrm{~m}$ from 2002 through 2009 with virioplankton abundance $\left(\times 10^{9} \mathrm{l}^{-1}\right)$ overlaid as contour lines. MLD (m) is superimposed as a white line in panel (a).

metric used to examine virioplankton dynamics in relation to potential hosts in marine systems is the ratio of virioplankton to total bacterioplankton (VBR; Wommack and Colwell, 2000; Suttle, 2007). Despite the vertical and temporal offsets between virioplankton and bacterioplankton maxima, the pairwise VBR was maintained within a narrow range (3-20) in $96 \%$ of the time-series measurements $(n=1458)$. The observed range of VBR values is consistent with previous studies in the marine environment (reviewed in Wommack and Colwell, 2000).

To further examine the relationship between virioplankton and total bacterioplankton abundances, the dynamics within the depth range of the virioplankton maximum $(60-100 \mathrm{~m})$ were investigated. Mean abundance data for the various parameters were determined by integrating values between 60 and $100 \mathrm{~m}$ and normalizing to integration depth. The mean virioplankton and total bacterioplankton maxima were weakly correlated through time $(r=0.24$, Table 2$)$. Only $6 \%$ of the variance in virioplankton abundance was explained by total bacterioplankton abundance variability for depth-normalized means between 60 and $100 \mathrm{~m}$ (Table 2). Annual composite plots focusing specifically on the temporal dynamics within the depth region of the virioplankton maxima were derived by integrating and depth-normalizing abundances between 60 and $100 \mathrm{~m}$ (Figure 3). The decade of data was then collapsed to a single annual composite where a mean value for each month was derived. The data revealed a slow accumulation of bacterioplankton from January through July as previously described (Steinberg et al., 2001), followed by a decrease in bacterioplankton between July and December. The decrease in bacterioplankton during periods of water column stratification coincides with a continued increase in virioplankton abundance, leading to an elevated VBR in the 60-100 $\mathrm{m}$ depth horizon (Figures $3 \mathrm{~b}$ and g).

The temporally offset dynamics between virioplankton and total bacterioplankton abundance, combined with the increasing VBR from July to December appear to be consistent with a classic predator-prey relationship described by a LotkaVolterra model. In accordance with this model, virioplankton deplete the population of susceptible bacterioplankton hosts, such that increases in virioplankton abundance coincide with decreases in abundance of their hosts ('kill the winner'; Thingstad and Lignell, 1997; Thingstad, 2000). To evaluate the appropriateness of this model to describe the annual patterns observed in this study, we utilized a simple form of the Lotka-Volterra predator-prey model (near equilibrium):

$$
P=\frac{2 \pi}{\sqrt{r d}}
$$

where $P$ is the period of the predator-prey cycle, $r$ is the specific growth rate of prey in the absence of predators and $d$ is the specific decay rate of predators (Murdoch et al., 2003). With specific growth rates of $0.2-1$ day $^{-1}$ for bacterioplankton and decay rates of $0.5-1.6$ day $^{-1}$ for virioplankton (Noble and Fuhrman, 2000), a period of 5-20 days was calculated. The derived period of this cycle is approximately 20-70-fold faster than the pattern observed in the annual composite plot (Figure 3b), indicating that predator-prey dynamics (which are dependent on bacterioplankton and virioplankton encounter and activity rates) are likely operating on shorter time scales than would be captured by monthly sampling.

\section{Virioplankton dynamics in the context of specific bacterioplankton lineages}

The lack of tight correlation between total virioplankton and bacterioplankton is not surprising given the known specificity of phage-host interactions and the high diversity of potential open 

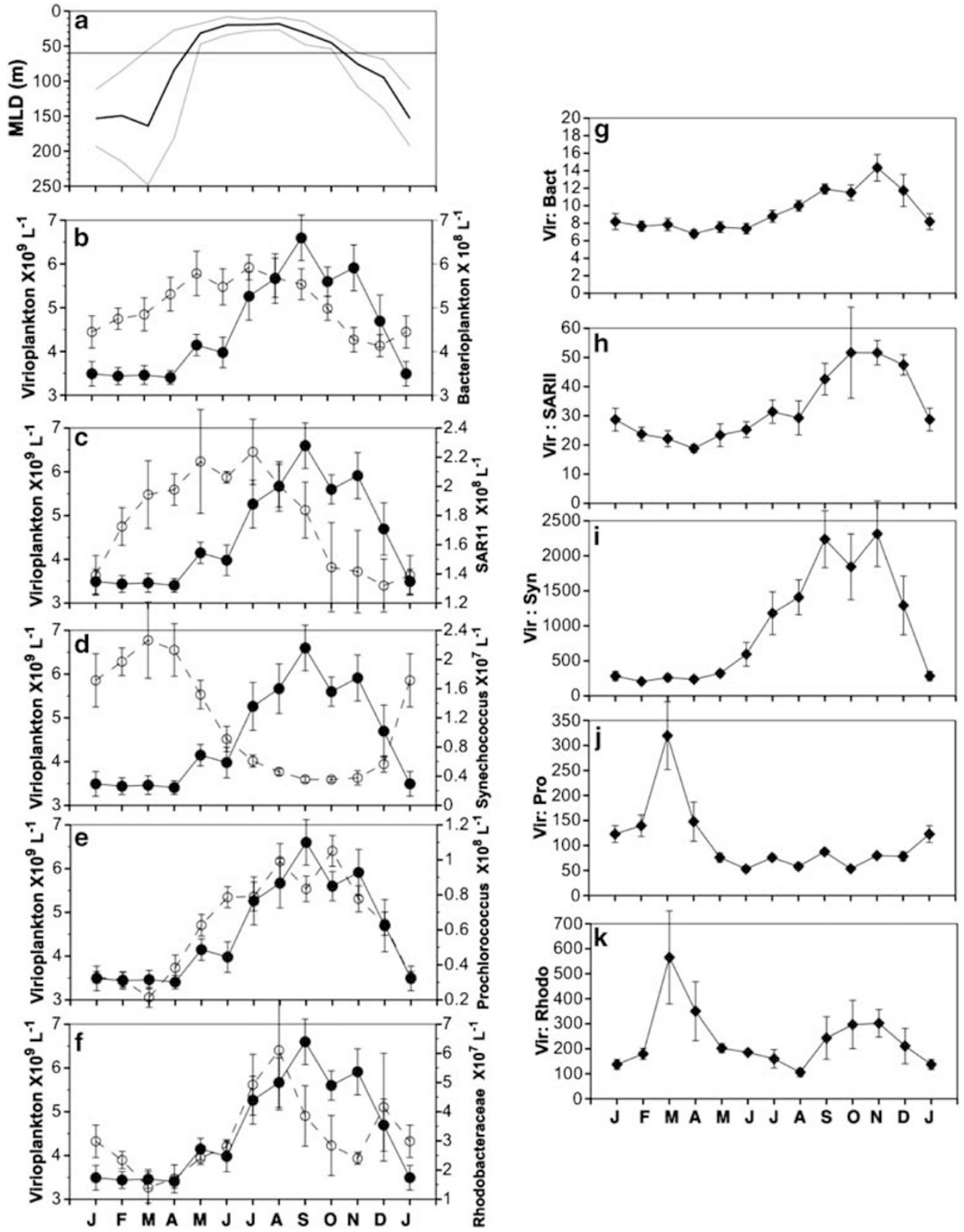

Figure 3 Annual composite plots of (a) $\mathrm{MLD}(\mathrm{m})$ in black with the total range in grey. (b) Virioplankton abundance $\left(\times 10^{9} \mathrm{l}^{-1}\right)($ filled circle) and bacterioplankton abundance $\left(\times 10^{8} \mathrm{l}^{-1}\right)$ (open circle; and for all bacterial lineages in the following panels). (c) Virioplankton abundance $\left(\times 10^{9} \mathrm{l}^{-1}\right)$ and SAR11 abundance $\left(\times 10^{8} \mathrm{l}^{-1}\right)$. (d) Virioplankton abundance $\left(\times 10^{9} \mathrm{l}^{-1}\right.$ and Synechococcus abundance $\left(\times 10^{7} l^{-1}\right)$. (e) Virioplankton abundance $\left(\times 10^{9} \mathrm{l}^{-1}\right)$ and Prochlorococcus abundance $\left(\times 10^{8} \mathrm{l}^{-1}\right)$. (f) Virioplankton abundance $\left(\times 10^{9} \mathrm{l}^{-1}\right)$ and Rhodobacteraceae abundance $\left(\times 10^{7} \mathrm{l}^{-1}\right)$. (g) VBR. (h) Virioplankton-to-SAR11 ratio. (i) Virioplankton-to-Synechococcus ratio. (j) Virioplankton-to-Prochlorococcus ratio and (k) virioplankton-to-Rhodobacteraceae ratio. The annual composite plots focused on the virioplankton maximum by integrating and depth-normalizing cell abundances between $60 \mathrm{~m}$ and $100 \mathrm{~m}$. The decadal time-series was then collapsed to a single annual composite where a mean value and standard error for each month was derived.

ocean bacterioplankton hosts (Giovannoni et al., 1990; Venter et al., 2004; Stingl and Giovannoni, 2005). Viral infection rates are dependent on contact rates with susceptible hosts (Murray and Jackson, 1992) so it is more likely that virioplankton abundance would be correlated with the specific bacterioplankton lineages that were producing the most viruses at the time of sample collection. The degree of viral pressure on specific prokaryotic lineages is extremely difficult to determine because measurement of virioplankton abundance by microscopy is restricted to the total community and cannot be subdivided by host range. However, the sign and degree of correlation (on monthly time scales) between the absolute ratio of total virioplankton abundance and the abundance of specific bacterioplankton host lineages can provide useful insights regarding the subsets of the 
Table 2 Pearson's correlation table showing $r$-values, $P$-values (two-tailed $T$-test with unequal variances) and $n$-values for Bacteria (2000-2009), Prochlorococcus (2002-2009), Synechococcus (2002-2009), SAR11 (2003-2005) and Rhodobacteracea (20032005) compared with virioplankton abundance for mean values between 60 and $100 \mathrm{~m}$ for all data points, and for subsets where the MLD $<50 \mathrm{~m}$ and MLD $>50 \mathrm{~m}$

\begin{tabular}{lll}
\hline $\begin{array}{l}\text { All data } \\
\text { January-December }\end{array}$ & $\begin{array}{c}\text { MLD }<50 \mathrm{~m} \\
\text { May-November }\end{array}$ & $\begin{array}{c}\text { MLD }>50 \mathrm{~m} \\
\text { December-April }\end{array}$ \\
\hline Bacterioplankton & & \\
$r=0.24$ & $r=0.34$ & $r=-0.10$ \\
$P=0.0013$ & $P=0.0168$ & $P=0.0189$ \\
$n=131$ & $n=65$ & $n=66$ \\
& & \\
Prochlorococcus & $r=0.55$ & $r=0.74$ \\
$r=0.66$ & $P<0.0001$ & $P<0.0001$ \\
$P<0.0001$ & $n=45$ & $n=52$ \\
$n=97$ & & \\
Synechococcus & $r=-0.41$ & $r=-0.41$ \\
$r=-0.44$ & $P<0.0001$ & $P<0.0001$ \\
$P<0.0001$ & $n=47$ & $n=52$ \\
$n=99$ & & \\
SAR11 & & $r=-0.28$ \\
$r=-0.02$ & $r=-0.12$ & $P<0.0001$ \\
$P<0.0001$ & $P<0.0001$ & $n=23$ \\
$n=42$ & $n=19$ & \\
& & $r=0.35$ \\
Rhodobacteracea & & $P<0.0001$ \\
$r=0.48$ & $r=0.45$ & $n=23$ \\
$P<0.0001$ & $P=0.044$ & \\
$n=42$ & $n=19$ & \\
\hline
\end{tabular}

Abbreviation: MLD, mixed layer depth.

bacterioplankton community that potentially drive virioplankton dynamics. Despite high bacterioplankton diversity in the Sargasso Sea (Giovannoni et al., 1990; Venter et al., 2004), a few specific lineages such as Prochlorococcus, Synechococcus, and SAR11 together comprise $>40 \%$ of the total prokaryotic community within the euphotic zone at BATS (Durand et al., 2001; Carlson et al., 2009; Treusch et al., 2009) and were therefore examined in detail.

\section{SAR11}

Members of the alpha-proteobacteria SAR11 clade represent a dominant heterotrophic bacterioplankton lineage in the subtropical gyres (Giovannoni et al., 1990; Morris et al., 2002, 2005; Carlson et al., 2009). SAR11 are ubiquitously distributed and represent $20-40 \%$ of the total bacterioplankton community in open ocean systems (Morris et al., 2002; Rappe et al., 2002). Members of the SAR11 clade such as Pelagibacter ubique have a relatively low specific growth rate when grown in pure culture on seawater (that is, 0.4-0.58 day ${ }^{-1}$; Rappe et al., 2002) or in mixed culture when amended with organic matter compared with other lineages that have a specific growth rate $>1$ day $^{-1}$ (Carlson, unpublished data).
Table 3 Mean and s.d. of the percent contribution of Prochlorococcus (2002-2009), Synechococcus (2002-2009), SAR11 (2003-2005) and Rhodobacteracea (2003-2005) to total bacteria abundance for mean values between 60 and $100 \mathrm{~m}$ for all data points, and for subsets where the MLD $<50 \mathrm{~m}$ and MLD $>50 \mathrm{~m}$

\begin{tabular}{|c|c|c|c|c|c|}
\hline \multicolumn{2}{|c|}{$\begin{array}{l}\text { All data points } \\
\text { January-December }\end{array}$} & \multicolumn{2}{|c|}{$\begin{array}{c}M L D<50 m \\
\text { May-November }\end{array}$} & \multicolumn{2}{|c|}{$\begin{array}{c}M L D>50 \mathrm{~m} \\
\text { December-April }\end{array}$} \\
\hline Mean & s.d. & Mean & s.d. & Mean & s.d. \\
\hline \multicolumn{6}{|c|}{ Prochlorococcus } \\
\hline $\begin{array}{l}12.1 \% \\
n=95\end{array}$ & $6.7 \%$ & $\begin{array}{l}14.6 \% \\
n=45\end{array}$ & $5.5 \%$ & $\begin{array}{l}10.1 \% \\
n=50\end{array}$ & $6.9 \%$ \\
\hline \multicolumn{6}{|c|}{ Synechococcus } \\
\hline $\begin{array}{l}2.6 \% \\
n=97\end{array}$ & $2.5 \%$ & $\begin{array}{l}1.7 \% \\
n=47\end{array}$ & $1.7 \%$ & $\begin{array}{l}3.4 \% \\
n=50\end{array}$ & $2.8 \%$ \\
\hline $\begin{array}{l}S A R 11 \\
34.6 \% \\
n=42\end{array}$ & $8.0 \%$ & $\begin{array}{l}33.8 \% \\
n=19\end{array}$ & $4.9 \%$ & $\begin{array}{l}34.6 \% \\
n=23\end{array}$ & $9.7 \%$ \\
\hline \multicolumn{6}{|c|}{ Rhodobacteracea } \\
\hline $\begin{array}{l}5.8 \% \\
n=42\end{array}$ & $4.3 \%$ & $\begin{array}{c}6.2 \% \\
n=19\end{array}$ & $3.1 \%$ & $\begin{array}{l}5.6 \% \\
n=23\end{array}$ & $5.2 \%$ \\
\hline
\end{tabular}

Abbreviation: MLD, mixed layer depth.

To evaluate the relationship between virioplankton dynamics and SAR11, FISH was used to quantify SAR11 abundance at BATS between 2003 and 2005. Throughout the time-series, SAR11 comprised $35 \% \pm 8 \%$ (s.d.) $(n=42)$ of the total bacterioplankton community for means between 60 and $100 \mathrm{~m}$ (Table 3). Similar to total bacterioplankton, the dynamics of mean SAR11 and virioplankton abundance between 60 and $100 \mathrm{~m}$ were offset temporally and vertically (Figures $3 \mathrm{c}$ and 4a), producing a weak negative correlation within that depth horizon $(r=-0.02$; Table 2$)$. The virioplankton-to-SAR11 ratio was maintained within a relatively narrow range of 20-50 (mean $31 \pm 14 ; n=42$ profiles) throughout the year (Figure $3 \mathrm{~h}$; Table 4 ). The virioplankton-to-SAR11 ratio was relatively stable from winter through summer and increased in autumn but did not vary systematically with MLD (Figure 3h, Table 4).

The temporal offset and negative correlation between SAR11 and total virioplankton abundances (Figures 3c and 4a), combined with the enhanced virioplankton-to-SAR11 ratio, could be attributed to a 'kill the winner' scenario where viral infection decimated SAR11 populations. However, from a logistical standpoint, repeatedly capturing this 'burst' event where the winners have recently been killed by the now-dominant viruses through a monthly sampling regime would be extremely fortuitous and statistically improbable. In addition, Suttle (2007) suggested that the 'kill the winner' scenario may be most applicable to $r$-selected organisms that respond rapidly to favorable conditions and have high metabolic activity. In fact, many 

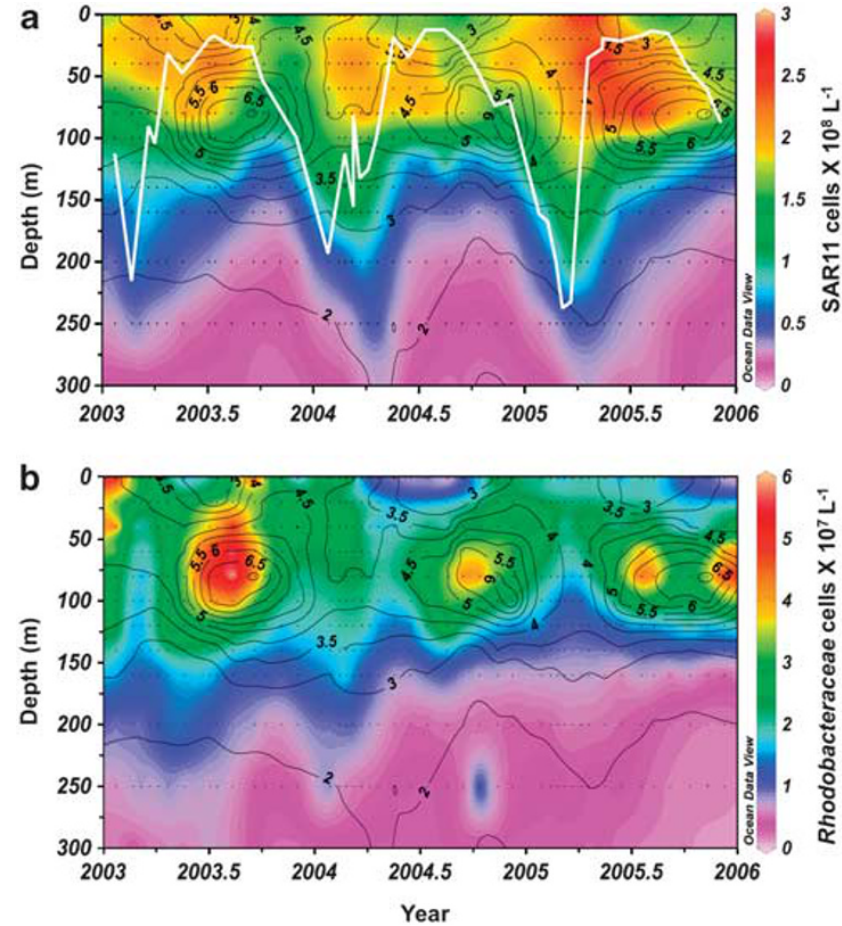

Figure 4 Contour plot of (a) SAR11 cell abundance $\left(\times 10^{8} \mathrm{I}^{-1}\right)$ and (b) Rhodobacteraceae $\left(\times 10^{7} \mathrm{l}^{-1}\right.$ ) cell abundance over $300 \mathrm{~m}$ from 2003 through 2005 with virioplankton abundance $\left(\times 10^{9} \mathrm{l}^{-1}\right)$ overlaid as contour lines. MLD (m) is superimposed as a white line in panel (a).

of the $r$-selected bacterioplankton may be the 'rarer' members of the microbial community whose high productivity is tightly coupled to high loss rates through viral infection. Bouvier and del Giorgio (2007) demonstrated that reduction of viral pressure within mesocosm experiments caused the 'rarer' bacterioplankton lineages to become dominant; consistent with the reasoning that viral infection actively controls the numerical dominance of $r$-strategists. Thus, the 'kill the winner' scenario may be queued to metabolic activity of the taxa rather than its absolute abundance. As SAR11 have lower specific growth rates than their $r$-selected counterparts, they are considered to be $k$-selected prokaryotic organisms (Suttle, 2007). Thus, their numerical dominance may be the result of reduced susceptibility to viral lysis (Suttle, 2007). Although SAR11 is a dominant component of the heterotrophic bacterial community (Morris et al., 2002), these results suggest that viruses infecting SAR11 comprise a disproportionally small percentage of the total virioplankton. This could be because SAR11 is a defense-specialist (Suttle, 2007), comprises multiple ecotypes (Field et al., 1997; Venter et al., 2004; Carlson et al., 2009; Treusch et al., 2009) or because the size and growth rates of SAR11 make it a suboptimal host. Phages have recently been isolated from SAR11 strains (Giovannoni personal communication) allowing future studies to further examine the impact of viral infection on this important host lineage.
Table 4 Mean and s.d. values of the VBR (2000-2009), VPR (2002-2009), virus-to-Synechococcus ratio (2002-2009), virus-toSAR11 ratio (2003-2005) and virus-to-Rhodobacteracea ratio (2003-2005) for mean values between 60 and $100 \mathrm{~m}$ for all data, and for subsets where the MLD $<50 \mathrm{~m}$ and MLD $>50 \mathrm{~m}$

\begin{tabular}{|c|c|c|c|c|c|}
\hline \multicolumn{2}{|c|}{$\begin{array}{l}\text { All data points } \\
\text { January-December }\end{array}$} & \multicolumn{2}{|c|}{$\begin{array}{c}M L D<50 m \\
\text { May-November }\end{array}$} & \multicolumn{2}{|c|}{$\begin{array}{c}M L D>50 \mathrm{~m} \\
\text { December-April }\end{array}$} \\
\hline Mean & s.d. & Mean & s.d. & Mean & s.d. \\
\hline \multicolumn{6}{|l|}{$V B R$} \\
\hline $\begin{array}{l}9.2 \\
n=129\end{array}$ & 3.5 & $\begin{array}{l}9.1 \\
n=65\end{array}$ & 2.7 & $\begin{array}{l}9.5 \\
n=64\end{array}$ & 4.3 \\
\hline \multicolumn{6}{|l|}{$V P R$} \\
\hline $\begin{array}{l}120.8 \\
n=95\end{array}$ & 120.9 & $\begin{array}{l}69.8 \\
n=45\end{array}$ & 24.3 & $\begin{array}{l}157.5 \\
n=50\end{array}$ & 139.0 \\
\hline \multicolumn{6}{|c|}{ Virus: synechococcus } \\
\hline $\begin{array}{l}897.3 \\
n=97\end{array}$ & 1025.7 & $\begin{array}{l}1065.2 \\
n=47\end{array}$ & 881.6 & $\begin{array}{l}800.9 \\
n=50\end{array}$ & 1157.1 \\
\hline $\begin{array}{c}\text { Virus: } S A R \\
\quad 31.0 \\
n=42\end{array}$ & 14.0 & $\begin{array}{l}29.8 \\
n=19\end{array}$ & 10.0 & $\begin{array}{l}32.9 \\
n=23\end{array}$ & 16.8 \\
\hline \multicolumn{6}{|c|}{ Virus: Rhodobacteracea } \\
\hline $\begin{array}{l}270.3 \\
n=42\end{array}$ & 239.2 & $\begin{array}{l}193.5 \\
n=19\end{array}$ & 106.4 & $\begin{array}{l}318.7 \\
n=23\end{array}$ & 292.8 \\
\hline
\end{tabular}

Abbreviations: MLD, mixed layer depth; VBR, virus-to-bacterium ratio; VPR, virus-to-Prochlorococcus ratio.

\section{Synechococcus}

Synechococcus are important picophytoplankton in the subtropical gyres with maximum abundance occurring in the spring within the mixed layer (Durand et al., 2001). Synechococcus abundance, determined by flow cytometry, averaged only $2.6 \pm 2.5 \%$ (s.d.) $(n=97)$ of the bacterioplankton community for means within the depth range of the virioplankton maxima (60-100 m; Table 3). Similar to SAR11, the Synechococcus dynamics were decoupled from virioplankton dynamics both temporally and vertically (Figure 2b). Consistent with previous observations (Durand et al., 2001), Synechococcus maxima developed shortly after water column stratification and were located shallower (that is, $20-60 \mathrm{~m}$ ) than the virioplankton maxima (Figure 2b). Synechococcus abundance was inversely correlated with virioplankton abundance $(r=-0.44)$ for means within the $60-100 \mathrm{~m}$ depth horizon (Figures 2b and 3d; Table 2).

The significant inverse correlation between virioplankton and Synechococcus abundances over an annual time frame (Figure $3 \mathrm{~d}$ ) is again suggestive of a 'kill the winner' scenario; however, several lines of evidence argue against Synechococcus driving the dominant virioplankton patterns at BATS. Similar to the rationale presented above for total bacterioplankton, when one considers Synechococcus specific growth rates that range between 0.5 and 1.2 day $^{-1}$ in the Sargasso Sea (Iturriaga and Marra, 1988) and cyanophage decay rates that range from 
0.12 to 2 day $^{-1}$ (Suttle and Chen, 1992), the predicted predator-prey period would range between 4 and 24 days (Equation (1)). This predicted period is significantly shorter than the seasonal time scales where patterns in Synechococcus and virioplankton abundances were observed in this study. It has been suggested that some Synechococcus strains have low infection efficiency based on positively correlated and synchronous patterns of Synechococcus and culturable cyanophages in which elevated abundances of both phages and hosts were maintained for long time periods (Waterbury and Valois, 1993). In accordance with the field observations, laboratory experiments have demonstrated that Synechococcus can readily develop resistance to cyanophages, with the cost of resistance varying depending on the identity of the phages (Lennon et al., 2007). If synchronous patterns of Synechococcus and virioplankton were sustained at BATS, it would not produce a typical predator-prey oscillating cycle as observed in this study. However, the Waterbury and Valois study was performed in a coastal system, and there is some evidence suggesting that Synechococcus in the open ocean may be less resistant to viral infection than coastal strains (Suttle and Chen, 1992). Finally, considering the abundance of Synechococcus hosts $\left(10^{6}-10^{7}\right.$ cells $\mathrm{l}^{-1}$ ), it is likely that the dynamics of cyanophages infecting Synechococcus, while present, are obscured within the signal of the total virioplankton community. The mean virioplankton-to-Synechococcus ratio was extremely high and variable $(1000$ to $>2000$ ) between 60 and $100 \mathrm{~m}$ during July through December (Figure 3i; Table 4) and this value greatly exceeds the burst size of cultured cyanophage that infect Synechococcus (Suttle and Chen, 1992).

\section{Prochlorococcus}

Prochlorococcus are numerically dominant in the subtropical gyres (Durand et al., 2001), and averaged $12.1 \pm 6.7 \%$ s.d. ( $n=95$ profiles $)$ of the total bacterioplankton community for means between 60 and $100 \mathrm{~m}$ in this study (Table 3). Prochlorococcus demonstrated regular annual patterns with abundance maxima developing between 60 and $100 \mathrm{~m}$ during periods of water column stratification in each year of the time-series (Figure 2c). As the MLD extended into the abundance maxima, a portion of the Prochlorococcus population was redistributed into the shallower depths, similar to the redistribution observed for virioplankton. The distribution patterns of Prochlorococcus and virioplankton were tightly coupled over depth and through time (Figures 2c and 3e). Interannual variability in the magnitude of the subsurface maximum of Prochlorococcus and virioplankton also coincided. For example, both variables had reduced abundances in 2008 (Figure 2c). Mean Prochlorococcus and virioplankton abundances were highly positively correlated $(r=0.66)$, explaining $44 \%$ of the variance in virio- plankton abundance between 60 and $100 \mathrm{~m}$ (Table 2). The virioplankton-to-Prochlorococcus ratio varied (Figure 3j; Table 4) considerably for all data points where the MLD $>50 \mathrm{~m} \quad(157.5 \pm 139.0 ; n=50$ profiles). However, when the water column stratified and MLD shoaled to $<50 \mathrm{~m}$, the virioplanktonto-Prochlorococcus ratio remained relatively stable between 50 and 90 (Figure 3j, Table 4), consistent with burst sizes of known marine phages (Wommack and Colwell, 2000).

Synchronous trends between the abundances of Synechococcus and cyanophages that could be cultured on laboratory Synechococcus strains have been previously observed (Waterbury and Valois, 1993; Sandaa and Larsen, 2006). In the central Pacific and Southern Oceans, the combined abundance of three groups of photoautotrophic picoplankton (Synechococcus, picoeukaryotes and Prochlorococcus) accounted for $57 \%$ of the variability in total virioplankton abundance, with Synechococcus abundance as the primary driver (Yang et al., 2010). Here, we observe a similar trend between abundances of virioplankton and Prochlorococcus. Notably in 2002-2003 and 2008, Prochlorococcus abundances do not increase to the same levels as in all other years of this study (Figure 2c), and correspondingly, virioplankton abundances are also drastically reduced compared with other years (Figure 1). Stable bacterioplankton host populations can be maintained during periods of high virioplankton if a significant fraction of the hosts are resistant to co-occurring phages (Waterbury and Valois, 1993), either through acquired resistance or high natural diversity of phage susceptibility types.

Given the highly correlated annual pattern of virioplankton and Prochlorococcus abundances within the 60-100 m depth horizon ( $r=0.66$; Table 2$)$ and the stable virioplankton-to-Prochlorococcus ratio for the majority of the stratified periods, it appears that a large fraction of the virioplankton dynamics is driven by the temporal variability of Prochlorococcus. The significant role of cyanophage is supported by the fact that Prochlorococcus phages can be readily isolated from the BATS site (Sullivan et al., 2003), and the frequent identification of sequences related to cultured Prochlorococcus phages in Sargasso Sea metagenomes (Angly et al., 2006; Williamson et al., 2008). Although the linkages between virioplankton and Prochlorococcus are purely correlative, the striking correspondence in their dynamics throughout the entire 10-year time-series suggests that the majority of the virioplankton at BATS may be cyanophages. Combined with the observations of Yang et al (2010) in the Pacific, these data indicate that cyanophages are an important component of marine virioplankton communities. If true, the dominance of cyanophages in open ocean systems has significant biogeochemical implications. Viral-mediated lysis of cyanobacteria could benefit the picophytoplankton population through the release of macro- and 
micro-nutrients. Viral lysis of host cells converts particulate material to labile suspended or dissolved materials such as amino acids and nucleic acids, effectively resulting in the retention of nitrogen, phosphorous and iron within the depth horizon of the Prochlorococcus maximum (Fuhrman, 1999; Poorvin et al., 2004; Suttle, 2007).

\section{Rhodobacteraceae}

Although SAR11 dominate the heterotrophic bacterioplankton community at BATS, numerous other bacterial lineages are present at lower concentrations. Virioplankton produced through lysis of these other hosts also contribute to the total observed virioplankton dynamics. FISH was also used to examine the dynamics of one of these 'rarer' lineages, the Rhodobacteraceae, between 2003 and 2005. The Rhodobacteraceae are a clade of heterotrophic alpha-proteobacteria that includes Roseobacter spp. Members of Rhodobacteraceae are quite dynamic at the BATS site, yet comprise a minor component of the total bacterioplankton community within the surface $300 \mathrm{~m}$ (Figure 4b). Rhodobacteraceae maxima occurred within the $60-100 \mathrm{~m}$ depth horizon during stratified periods, where they comprised $5.8 \pm 4.3 \%$ (s.d.; $n=19$ profiles) of the total bacterioplankton community (Figure 4b, Table 3). The Rhodobacteraceae were positively correlated with virioplankton abundance $(r=0.48)$ for depthnormalized means within 60 and $100 \mathrm{~m}$ (Figures $4 \mathrm{~b}$ and 3f; Table 2), explaining $23 \%$ of the variance in virioplankton abundance.

Despite the fact that they are capable of rapid growth, Roseobacter spp. are commonly found at low abundances in oligotrophic waters (Alonso and Pernthaler, 2006). Phages infecting Roseobacter spp. can easily be cultured from seawater (Rohwer et al., 2000; Angly et al., 2009; Zhao et al., 2009), and sequences similar to roseophages are abundant in marine metagenomes (Breitbart et al., 2002; Angly et al., 2006). It has previously been suggested that many of the 'rarer' taxa present in oceanic systems (such as Roseobacter spp.) are $r$-strategists that are growing rapidly but never become dominant community members because they suffer high losses because of viral lysis (Fuhrman and Schwalbach, 2003; Bouvier and del Giorgio, 2007; Suttle, 2007). Although this scenario of viral control on $r$-strategists is indeed possible, the extremely high virioplankton to Rhodobacteraceae ratio (that is, 100-600) (Figure 3k, Table 4) is greater than typical burst sizes reported in the literature for marine phages and it is unlikely that such interactions will contribute significantly to the overall observed variability in virioplankton abundance at BATS. In addition, calculations demonstrate that the number of viruses potentially produced at any given time by a burst of all the Rhodobacteraceae cells would still not be sufficient to produce the dominant virioplankton signal at BATS. Therefore, while the
Rhodobacteraceae data demonstrate that the dynamics of other lineages may also correlate with virioplankton dynamics, the true dynamics of virioplankton that target Rhodobacteraceae are likely obscured by those virioplankton infecting the more abundant bacterioplankton hosts.

\section{Conclusion}

This decadal study demonstrates recurring annual patterns in virioplankton abundance in the North Atlantic subtropical gyre directly related to the dynamics of specific bacterioplankton lineages in response to physical changes in water column stability. This data set reveals a striking correlation between total virioplankton abundance and the abundance of Prochlorococcus that has not been previously described, suggesting that Prochlorococcus dynamics are a major driver of virioplankton dynamics. The differing strengths and signs of the correlations between total virioplankton abundance and the abundance of the specific lineages Prochlorococcus, Synechococcus, SAR11 and Rhodobacteraceae suggest that all members of the bacterioplankton community are not subject to the same levels of topdown pressure from viral infection. However, some viral control (specifically of Synechococcus and Rhodobacteraceae) may be obscured within the signal of the total virioplankton community. In addition, as Prochlorococcus correlated with viral abundance while SAR11 did not, viruses may have an important role in determining the balance between autotrophic and heterotrophic bacterioplankton in the open ocean. Correlative analyses comparing the abundances of total virioplankton and potential bacterioplankton hosts only suggest possible controls on virioplankton dynamics. Further phylogenetic identification of phages, experimental determination of viral pressure on specific host lineages and additional modeling exercises using these data are required to resolve the specific drivers of the systematic temporal variability in total virioplankton in the open ocean.

\section{Conflict of interest}

The authors declare no conflict of interest.

\section{Acknowledgements}

We are grateful to the officers and crew of the $R V$ Weatherbird II and RV Atlantic Explorer, the BATS chief scientists and technicians who assisted in sample collection. We thank the Giovannoni Laboratory at OSU for Rhodobacteraceae probe sequence. We thank J Casey for assistance in analyzing flow cytometric samples and $\mathrm{F}$ Rohwer and the SDSU math group, J Paul and C Nelson for comments and discussions on earlier versions of the paper. This work was supported by NSF Microbial Observatory and Emerging Topics in Biogeochemistry 
programs MCB-9977918, MCB-0237728, OCE- 0801991 to CAC and Microbial Interactions and Processes Grant MCB0701984 to MB and Bermuda Atlantic Time-Series Study Grants OCE0326885, OCE-0752366 to MWL.

\section{References}

Alonso C, Pernthaler J. (2006). Roseobacter and SAR11 dominate microbial glucose uptake in coastal North Sea waters. Environ Microbiol 8: 2022-2030.

Angly F, Felts B, Breitbart M, Salamon P, Edwards R, Carlson $\mathrm{C}$ et al. (2006). The marine viromes of four oceanic regions. PLoS Biol 4: e368.

Angly F, Youle M, Nostrat B, Srinagesh S, Rodriguez-Brito B, McNairnie P et al. (2009). Genomic analysis of multiple Roseophage SIO1 strains. Environ Microbiol 11: 2863-2873.

Bergh, Børsheim KY, Bratbak G, Heldal M. (1989). High abundance of viruses found in aquatic environments. Nature 340: 467-468.

Boehme J, Frischer ME, Jiang SC, Kellogg CA, Pichard S, Rose JB et al. (1993). Viruses, bacterioplankton, and phytoplankton in the southeastern Gulf of Mexico: distribution and contribution to oceanic DNA pools. Mar Ecol Prog Ser 97: 1-10.

Bouvier T, del Giorgio P. (2007). Key role of selective viral-induced mortality in determining marine bacterial community composition. Environ Microbiol 9: 287-297.

Breitbart M, Salamon P, Andresen B, Mahaffy JM, Segall AM, Mead D et al. (2002). Genomic analysis of uncultured marine viral communities. Proc Natl Acad Sci USA 99: 14250-14255.

Carlson C, Morris R, Parsons R, Treusch A, Giovannoni S, Vergin K. (2009). Seasonal dynamics of SAR11 populations in the euphotic and mesopelagic zones of the northwestern Sargasso Sea. ISME J 3: 283-295.

Carlson CA, Ducklow HW. (1996). Growth of bacterioplankton and consumption of dissolved organic carbon in the oligotrophic Sargasso Sea. Aquat Microb Ecol 10: 69-85.

Carlson CA, Ducklow HW, Sleeter TD. (1996). Stocks and dynamics of bacterioplankton in the northwestern Sargasso Sea. Deep Sea Res II 43: 491-515.

Casey J, Lomas M, Mandecki J, Walker D. (2007). Prochlorococcus contributes to new production in the Sargasso Sea deep chlorophyll maximum. Geophysical Res Lett 34: L10604.

Cochlan WP, Wikner J, Steward GF, Smith DC, Azam F. (1993). Spatial distribution of viruses, bacteria, and chlorophyll a in neritic, oceanic, and estuarine environments. Mar Ecol Prog Ser 92: 77-87.

Culley A, Welschmeyer N. (2002). The abundance, distribution, and correlation of viruses, phytoplankton, and prokaryotes along a Pacific Ocean transect. Limnol Oceanography 47: 1508-1513.

de Araujo M, Godinhoa M. (2009). Short-term variations of virus-like particles in a tropical lake: relationship with microbial communities (bacteria, ciliates and flagellates). Microbiol Res 164: 411-419.

Dinsdale E, Edwards R, Hall D, Angly F, Breitbart M, Brulc J et al. (2008). Functional metagenomic profiling of nine biomes. Nature 452: 629-633.
Durand M, Olson R. (1996). Contributions of phytoplankton light scattering and cell concentration changes to diel variations in beam attenuation in the equatorial Pacific from flow cytometric measurements of pico-, ultra- and nanoplankton. Deep Sea Res II 43: 891-906.

Durand M, Olson R, Chisholm S. (2001). Phytoplankton population dynamics at the Bermuda Atlantic Time-series station in the Sargasso Sea. Deep Sea Res II 48: 1983-2003.

Field KG, Gordon D, Wright T, Rappe M, Urbach E, Vergin K et al. (1997). Diversity and depth-specific distribution of SAR 11 cluster rRNA genes from marine planktonic bacteria. Appl Environ Microbiol 63: $63-70$.

Fuhrman J. (1999). Marine viruses: biogeochemical and ecological effects. Nature 399: 541-548.

Fuhrman J, Schwalbach M. (2003). Viral influence of aquatic bacterial communities. Biological Bull 204: 192-195.

Giovannoni SJ, Britschgi TB, Moyer CL, Field KG. (1990). Genetic diversity in Sargasso Sea bacterioplankton. Nature 345: 60-63.

Guixa-Boixareu N, Vaque D, Gasol J, Pedros-Alio C. (1999). Distribution of viruses and their potential effect on bacterioplankton in an oligotrophic marine system. Aquat Microb Ecol 19: 205-213.

Hara S, Koike I, Terauchi K, Kamiya H, Tanoue E. (1996). Abundance of viruses in deep oceanic waters. Mar Ecol Prog Ser 145: 269-277.

Iturriaga R, Marra J. (1988). Temporal and spatial variability of chroococcoid cyanobacteria Synechococcus spp. specific growth rates and their contribution to primary production in the Sargasso Sea. Mar Ecol Prog Ser 44: 175-181.

Jiang SC, Paul JH. (1994). Seasonal and diel abundance of viruses and occurrence of lysogeny/bacteriocinogeny in the marine environment. Mar Ecol Prog Ser 104: 163-172.

Lennon JT, Khatana SAM, Marston MF, Martiny JBH. (2007). Is there a cost of virus resistance in marine cyanobacteria? ISME J 1: 300-312.

Lomas MW, Steinberg DK, Dickey T, Carlson CA, Nelson $\mathrm{N}$, Condon RH et al. (2010). Increased ocean carbon export in the Sargasso Sea linked to climate variability is countered by its enhanced mesopelagic attenuation. Biogeosciences 7: 57-70.

Marchant H, Davidson A, Wright S, Glazebrook J. (2000). The distribution and abundance of viruses in the Southern Ocean during spring. Antarctic Sci 12: 414-417.

Morris R, Rapp M, Connon S, Vergin K, Siebold W, Carlson CA et al. (2002). SAR11 clade dominates ocean surface bacterioplankton communities. Nature 420: 806-810.

Morris RM, Vergin KL, Cho JC, Rappe MS, Carlson CA, Giovannoni SJ. (2005). Temporal and spatial response of bacterioplankton lineages to annual convective overturn at the Bermuda Atlantic Time-series Study site. Limnol Oceanography 50: 1687-1696.

Murdoch W, Briggs C, Nisbet R. (2003). ConsumerResource Dynamics: Monographs in Population Biology. Princeton University Press: Princeton, NJ.

Murray AG, Jackson GS. (1992). Viral dynamics: a model of the effects of size, shape, motion and abundance of single-celled planktonic organisms and other particles. Mar Ecol Prog Ser 89: 103-116.

Noble R, Fuhrman J. (2000). Rapid virus production and removal as measured with fluorescently labeled 
viruses as tracers. Appl Environ Microbiol 66: 3790-3797.

Noble RT, Fuhrman JA. (1998). Use of SYBR green I for rapid epifluorescence counts of marine viruses and bacteria. Aquat Microb Ecol 14: 113-118.

Olson RJ, Chishlom SW, Zettler ER, Armbrust EV. (1990). Pigments, size, and distribution of Synechococcus in the North Atlantic and Pacific Oceans. Limnol Oceanography 35: 45-58.

Poorvin L, Rinta-Kanto J, Hutchins D, Wilhelm S. (2004). Viral release of iron and its bioavailability to marine plankton. Limnol Oceanography 49: 1734-1741.

Porter KG, Feig YS. (1980). The use of DAPI for identifying and counting aquatic microflora. Limnol Oceanography 25: 943-948.

Proctor LM, Fuhrman JA. (1990). Viral mortality of marine bacteria and cyanobacteria. Nature 343: 60-62.

Rappe M, Connon S, Vergin K, Giovannoni S. (2002). Cultivation of the ubiquitous SAR11 marine bacterioplankton clade. Nature 418: 630-633.

Rohwer F, Segall AM, Steward G, Seguritan V, Breitbart M, Wolven F et al. (2000). The complete genomic sequence of the marine phage Roseophage SIO1 shares homology with non-marine phages. Limnol Oceanography 42: 408-418.

Rohwer F, Thurber R. (2009). Viruses manipulate the marine environment. Nature 459: 207-212.

Rowe JM, Saxton MA, Cottrell MT, DeBruyn JM, Mine Berg G, Kirchman DL et al. (2008). Contraints on viral production in the Sargasso Sea and North Atlantic. Aquat Microb Ecol 52: 233-244.

Sandaa R, Larsen A. (2006). Seasonal variations in virushost populations in Norwegian coastal waters: focusing on the cyanophage community infecting marine Synechococcus spp. Appl Environ Microbiol 72: 4610-4618.

Sprintall J, Tomczak M. (1992). Evidence of the barrier layer in the surface layer of the tropics. J Geophysical Res 97: 7305-7316.

Steinberg D, Carlson C, Bates N, Johnson R, Michaels A, Knap A. (2001). Overview of the US JGOFS Bermuda Atlantic Time-series Study (BATS): a decade-scale look at ocean biology and biogeochemistry. Deep Sea Res II 48: 1405-1447.

Stingl U, Giovannoni S. (2005). Molecular diversity and ecology of microbial plankton. Nature 437: 343-348.

Sullivan M, Waterbury J, Chisholm S. (2003). Cyanophages infecting the oceanic cyanobacterium Prochlorococcus. Nature 424: 1047-1051.

Suttle C. (2007). Marine viruses-major players in the global ecosystem. Nat Rev Microbiol 5: 801-812.
Suttle C, Chen F. (1992). Mechanisms and rates of decay of marine viruses in seawater. Appl Environ Microbiol 58: 3721-3729.

Suttle CA. (1994). The significance of viruses to mortality in aquatic microbial communities. Microbial Ecol 28: 237-243.

Thingstad T. (2000). Elements of a theory for the mechanisms controlling abundance, diversity, and biogeochemical role of lytic bacterial viruses in aquatic systems. Limnol Oceanography 45: 1320-1328.

Thingstad TF, Lignell R. (1997). Theoretical models for the control of bacterial growth rate, abundance, diversity and carbon demand. Aquat Microb Ecol 13: 19-27.

Treusch A, Vergin K, Finlay L, Donatz M, Burton R, Carlson C et al. (2009). Seasonality and vertical structure of microbial communities in an ocean gyre. ISME J 3: 1148-1163.

Venter JC, Remington K, Heidelberg JF, Halpern AL, Rusch D, Eisen JA et al. (2004). Environmental genome shotgun sequencing of the Sargasso Sea. Science 304: 66-74.

Waterbury JB, Valois FW. (1993). Resistance to co-occurring phages enables marine Synechococcus communities to coexist with cyanophages abundant in seawater. Appl Environ Microbiol 59: 3393-3399.

Weinbauer M, Fuks D, Puskaric S, Peduzzi P. (1995). Diel, seasonal, and depth-related variability of viruses and dissolved DNA in the Northern Adriatic sea. Microbial Ecol 30: 25-41.

Weinbauer M, Suttle CA. (1999). Lysogeny and prophage induction in coastal and offshore bacterial communities. Aquat Microb Ecol 18: 217-225.

Wen K, Ortmann AC, Suttle CA. (2004). Accurate estimation of viral abundances by epifluorescence microscopy. Appl Environ Microbiol 70: 3862-3867.

Williamson S, Rusch D, Yooseph S, Halpern A, Heidelberg $\mathrm{K}$, Glass J et al. (2008). The Sorcerer II global ocean sampling expedition: metagenomic characterization of viruses within aquatic microbial samples. PLoS One 3: e1456.

Wommack K, Colwell R. (2000). Virioplankton: viruses in aquatic ecosystems. Microbiol Mol Biol Rev 64: 69-114.

Wommack KE, Hill RT, Muller TA, Colwell RR. (1996). Effects of sunlight on bacteriophage viability and structure. Appl Environ Microbiol 62: 1336-1341.

Yang Y, Motegi C, Yokokawa T, Nagata T. (2010). Largescale distribution patterns of virioplankton in the upper ocean. Aquat Microb Ecol 60: 233-246.

Zhao Y, Wang K, Jiao NZ, Chen F. (2009). Genome sequences of two novel phages infecting marine roseobacters. Environ Microbiol 11: 2055-2064. 